\title{
Foglalkozási rehabilitációt ösztönző rendszerek - nemzetközi gyakorlatok
}

\section{Definíciók}

Az elmúlt évtizedekben bizonyos fokig letisztultak azok a viták, amelyek a fogyatékossággal élő és megváltozott munkaképességú személy fogalmának különbözőségét prezentáltak. Az Európai Unióban a tagországok általános alapként az ENSZ Egyezmény meghatározásából indulnak ki: „ffogyatékossággal élő személy minden olyan személy, aki hosszan tartó fizikai, értelmi, szellemi vagy érzékszervi károsodással él, amely számos egyéb akadállyal együtt korlátozhatja az adott személy teljes, hatékony és másokkal egyenlő társadalmi szerepvállalását."

Ezen alapfogalom alapján az Egészségügyi Világszervezet (World Health Organization, WHO) szerint „a fogyatékosság a károsodásokat, a tevékenység akadályozottságát és a részvétel korlátozottságát felölelő gyüjtöfogalom. Egy kóros egészségi állapotú egyén, valamint kontextuális (környezeti és személyes) tényezői közötti kölcsönhatás negatív oldalát jelöli meg."

A Nemzetközi Munkaügyi Szervezet (International Labour Organization, ILO) szerint a „megváltozott munkaképességü, fogyatékos személy az, akinek állásszerzési, állásban maradási és elömeneteli kilátásai lényegesen romlottak, testi vagy értelmi képességeinek hivatalosan megállapított megváltozása miatt."

Ugyanakkor a nemzetek a definíció lebontása során, elsősorban szakpolitikai megközelítésben, különösen az eszközrendszerek tekintetében számos eltérő, döntően a jogosultsághoz köthető fogalmat, illetve tartalmat alkalmaznak. Így például Németországban és Ausztriában a támogatottsági limit alsó határa a fogyatékossággal élő személy $50 \%$-os egészségkárosodása vagy megváltozott munkaképessége, míg Szlovákiában ez a határ 40\%-os.

A fogalmi tisztázás mellett fontossá vált az is, hogy az uniós országok mindennapi gyakorlatában elfogadottá vált az FNO (Funkcióképesség, fogyatékosság és egészség nemzetközi osztályozása) alkalmazása. Az FNO szerint a munka vállalásának, megtartásának és az abban való előrehaladásnak az esélyeit számtalan tényező befolyásolhatja. Ilyen tényezők lehetnek azok az adott testi funkciók (mentális, érzékelési, hang és beszéd stb.) és struktúrák, amelyek egyes munkakörök betöltését kizárják, korlátozzák, míg más munkakörök betöltését azonban nem befolyásolhatják. Lényeges elemek a kognitív kompetenciák, amelyek a munkavállaláshoz szükséges ismereteket, képességeket tartalmazzák és meghatározóak a környezeti tényezők, mint például az akadálymentesség a munkahelyi befogadás stb. ${ }^{1}$

Mindemellett számos kérdés befolyásolja a fogyatékkal élő személyek kapacitását a foglalkoztatáshoz és a foglalkoztatásban való előrehaladáshoz. Az oktatási akadályok, az ésszerū elhelyezkedés hiánya, az infrastruktúrákhoz és az információhoz való hozzáférés hiánya, a jogképességgel kapcsolatos korlátozások és a társadalomban lévő attitúdkorlátozások olyan területek, amelyek jelentős hatást gyako-

\footnotetext{
${ }^{1}$ Szellő János (szerk.) (2013): A rehabilitációs kvóta és hozzájárulás hatása a munkáltatók befogadói magatartására Magyar-
} országon. Kutatási zárótanulmány. Készült a „Közösen a jövő munkahelyeiért” Alapítvány támogatásával. PTE, Pécs 
rolnak a fogyatékkal élők foglalkoztatására. Ráadásul, sok fogyatékkal élő embert inaktívnak nyilvánítanak, a legtöbbjüket nem regisztrálják álláskeresőként, ezáltal a fogyatékosság gyakran munkaképtelenségnek tekinthető.

\section{Stratégiák és politikák}

A fogyatékossággal élő személyek jogairól szóló ENSZ Egyezmény meghatározza e célcsoport munkavállaláshoz való jogát, amely magában foglalja

- a számukra nyitott, befogadó és hozzáférhető munkaerő-piacon

- szabadon választott és elfogadott munka révén nyerhető megélhetés lehetőségének jogát,

- a munkához való jog érvényesülését és érvényesítését.

Megtilt mindennemű, a fogyatékosság alapján történő, a munkavállalás bármely formájával kapcsolatos hátrányos megkülönböztetést, beleértve a munkaerő-toborzás, az alkalmazás és a foglalkoztatás feltételeit, a foglalkoztatás folytonosságát, a szakmai előmenetelt, valamint a biztonságos és egészséges munkakörülményeket.

Az Egyezmény többek között kiemeli, hogy a tagállamoknak a fogyatékossággal élő személyek számára biztosítania kell az

- általános szakmai és pályaválasztási tanácsadói programokhoz,

- a közvetítői szolgáltatásokhoz, valamint

- a szakképzéshez és továbbképzésekhez való hozzáférést.

További követelmény, hogy a tagállamok segítsék a fogyatékossággal élő személyek munkatapasztalatszerzését a nyílt munkaerőpiacon, támogassák a fogyatékossággal élő személyeknek szóló szakképzési és szakmai rehabilitációt, a munkában-tartási és munkába való visszatérést segítő programokat. ${ }^{2}$

Az Európai Unió a hátrányos helyzetű csoportok, a fogyatékossággal élők és a megváltozott munkaképességű személyek érdekében végzett politikája részeként, mainstreaminget előirányzó közelítést végzett. $^{3}$

Ennek következményeként az unió irányelvei arra irányulnak, hogy szélesebb körú politikákat dolgozzanak ki a hátrányos csoportokra, de nem határoznak meg részletes javaslatokat e csoportok speciális igényeire bontva. A tagországok feladata, hogy úgy építsék fel a saját nemzeti politikájukat az EU irányelvei figyelembevételével, hogy ezek a politikák és az azokat követő intézkedések teljes mértékben hozzáférhetőek legyenek a hátrányos helyzetű emberek számára. ${ }^{4}$

\footnotetext{
${ }^{2}$ www.un.org/disabilities/documents/natl/hungary.doc

${ }^{3}$ A mainstreaming közelítésmód azt jelenti, hogy a hátrányok kezelésének egyik legfontosabb eszköze az egyenlő esélyú hozzáférés, a fokozottan személyszabott megközelítés biztosítása, az elérhető eredmények főáramba helyezésének igénye és szándéka.

${ }^{4}$ Disability mainstreaming int he European Employment Strategy, European Commission, Employment, Social Affairs and Equal Opportunities Dg, Brussels, 1/07/2005
} 
A politikákon belüli mainstreaming elve alkalmazására vonatkozó igény jogi háttere az EU diszkriminációk elleni direktíváiban került lefektetésre, amikor is megtiltották a vallási, meggyőződésbeli, fogyatékossági, életkori és nemek szerinti megkülönböztetést az élet minden területén, ezen belül a hivatásban és foglalkoztatásban is.

A közelítésmód alkalmazásával hangsúlyossá vált a hátránykezelés főáramba helyezésének igénye. Ez azt jelenti, hogy elsősorban a foglalkoztatás elősegítése érdekében múködtetett általános munkaerőpiaci programokat kell alkalmazni a hátrányos csoportok, fogyatékossággal élő és megváltozott munkaképességű emberek esetében is. Egyre szúkíteni, illetve specializálni kell azoknak a speciális támogatásoknak, eszközöknek a körét, amelyek a szegregált foglalkoztatást szolgálják. Azaz az integrációt nem csak a foglalkoztatás megvalósulásában, hanem az ezt megelőző rehabilitációs folyamatban is fontosnak tartják.

A főáramba helyezés (intenzív tanácsadás; képzés, átképzés; foglalkoztatási és vállalkozási ösztönzők; közvetlen munkahelyteremtés) prioritása megköveteli a munkaerő-piaci programok ráfordításainak emelését, illetve hatékonyságuk növelését is. Ugyanakkor megjegyzendő, hogy az aktív integrációra irányuló koncepció sikeres alkalmazása a különféle elemek és tényezők (szakpolitikák, munkáltatók, civil szféra stb.) közötti együttműködésen múlik. A megfelelő jövedelemtámogatást munkaerő-piaci lehetőségekkel és jó minőségű szolgáltatásokhoz való könnyebb hozzáféréssel kell kombinálni. Mindemellett a társadalmi integráció és a munkaerő-piaci részvétel nem válik el egymástól. ${ }^{5}$

A 2010-2020 közötti időszakra vonatkozó Európai Fogyatékosságügyi Stratégia átfogó célkitűzése az, hogy erősítse a fogyatékossággal élők pozícióját annak érdekében, hogy teljes mértékben élhessenek jogaikkal, és teljes körúen részt vehessenek a társadalomban és az európai gazdaságban, különösen az egységes piac keretében. A Bizottság nyolc cselekvési területet jelölt ki:

1. akadálymentesítés,

2. részvétel,

3. egyenlőség,

4. foglalkoztatás,

5. oktatás és képzés,

6. szociális védelem,

7. egészség,

8. külső fellépés.

Ezen belül a fogyatékossággal élő és megváltozott munkaképességű személyek munkavégzésével kapcsolatos fő üzenet továbbra is az integrált foglalkoztatás, az esélyegyenlőség, a lehetőség szerinti teljes élet elősegítése.

A stratégia fontos meghatározása a minőségi munkahelyek létrehozása, fejlesztése, mivel azok biztosítják a gazdasági függetlenséget, ösztönzik a személyes teljesítményeket, és a legmegfelelőbb védelmet nyújtják a szegénység ellen. A stratégia uniós támogatást nyújt a nemzeti intézkedéseknek, és a következő területeken kiegészíti őket:

- $\quad$ a fogyatékos személyek munkaerő-piaci helyzetének elemzése,

- $\quad$ fellépés olyan ellátási gyakorlatok és csapdák ellen, amelyek eltérítik a fogyatékos személyeket a munkaerő-piaci belépéstől,

\footnotetext{
${ }^{5}$ Szellő János (2009): A foglalkozási rehabilitáció elmélete és gyakorlata, jegyzet. ELTE BGGYK Budapest
} 
- $\quad$ az Európai Szociális Alap (ESZA) igénybe vételével a fogyatékos személyek munkaerőpiaci integrációjának elősegítése,

- $\quad$ aktív munkaerő-piaci politikák kidolgozása,

- a munkahelyek jobb akadálymentesítése,

- $\quad$ a munkaközvetítés, a támogatási struktúrák és a munkahelyi képzés számára szolgáltatások kidolgozása.

A Bizottság előzetes értesítése nélkül állami támogatás nyújtását lehetővé tevő általános csoportmentességi rendelet használatának ösztönzése nemzeti feladat. ${ }^{6}$

\section{Helyzetkép}

Az EUROSTAT adatai szerint Európában mintegy 80 millió fogyatékos személy él, és figyelemmel a demográfiai változásokra ez várhatóan 2020-ra eléri a 120 millió főt. A fogyatékos személyek esetében a szegénységi ráta 70 \%-kal magasabb az átlagnál, ami részben a foglalkoztatáshoz való korlátozott hozzáférésnek tulajdonítható. ${ }^{7}$

Az Európai Fogyatékosügyi Szakértők Akadémiai Hálózata (The Academic Network of European Disability Experts /ANED) felmérése alapján a fogyatékkal élő nők aránya a teljes népességben magasabb (29,5\%), mint a férfiaké $(24,5 \%) \cdot{ }^{8}$ 2013-ban európai szinten a 16 éves és idősebb személyek mintegy 26,9\%-a aktivitásában korlátozott volt, és a fogyatékkal élők foglalkoztatottsága (48,5\%) 23 százalékponttal alacsonyabb arányt mutatott, mint a nem fogyatékkal élőké (71,4\%). Nemek közötti megoszlásukat tekintve a nők foglalkoztatási rátája $45 \%$-ot, a férfiak foglalkoztatási mutatója pedig 52\%-ot tett ki. A súlyosan fogyatékos emberek foglalkoztatottsági aránya $29 \%$-os, a fogyatékossággal élők esetében $56 \%$-os, a nem fogyatékosoké pedig $71 \%$-os volt.

A megváltozott munkaképességú emberek gazdasági aktivitási mutatói nagyon kedvezőtlenek, a munkaerőpiacon erősen alulreprezentáltak. A gazdasági aktivitási mutató (15-64 éves korcsoport) 58,9\%os arányával szemben a nem megváltozott munkaképességű személyekével, amely 81,0\%-os (a teljes arány 76,8\%) az adott időszakban. Az aktivitási ráta különösen alacsony Máltán, Írországban és Romániában és viszonylag magas Finnországban, Németországban és Svédországban. A fogyatékkal élők személyek uniós munkanélküliségi rátája 19,0\%-os, szemben a nem fogyatékkal élők 11,8\%-ával. A fogyatékkal élő emberek munkanélküliségi mutatója viszonylag alacsony Romániában (5,6\%), Hollandiában (10,3\%), és az Egyesült Királyságban (12,5\%). Az átlagnál magasabb volt Spanyolországban $(36,1 \%)$, Horvátországban (37,1\%) és Görögországban (39,2\%). ${ }^{9}$

Az EU által használt és a ANED jelentéseiben részletesen elemzett mutatókat az 1. sz. táblázat foglalja össze.

\footnotetext{
${ }^{6}$ Európai fogyatékosságügyi stratégia 2010-2020: megújított elkötelezettség az akadálymentes Európa megvalósítása iránt. COM(2010) 636 végleges. Brüsszel, 2010.11.15.

7 EU SILC 2014.

${ }^{8}$ A mutatókra vonatkozó adatok az EU-SILC 2014-ből származnak. Az EU-SILC az elmúlt 6 hónapban az egészségügyi problémák miatt "saját tevékenységre korlátozott" kérdésekre adott saját válaszai alapján készült, és a fogyatékosság proxyjaként használják. Az EU-SILC minden 16 éves és annál idősebb személyre kiterjed, aki magánháztartásokban él. Nem vonatkozik a gyermekekre vagy a bentlakásos intézményekben élő emberekre. Az éves mutatókat az EU-SILC adatai alapján állítja össze az ANED.

${ }^{9}$ Grammenos, Stefanos (2015): European comparative data on Europe 2020 \& People with disabilities. Draft report. Academic Network of European Disability experts (ANED). Centre for European Social and Economic Policy (CESEP ASBL. Bruxelles
} 
1. sz. táblázat: Az EU által használt főbb indikátorok összefoglalása

\begin{tabular}{|c|c|c|c|c|c|c|}
\hline & 2008 & 2009 & 2010 & 2011 & 2012 & 2013 \\
\hline $\begin{array}{l}\text { Fogyatékos személyek } \\
\text { aránya (16+ év) }\end{array}$ & $25,1 \%$ & $25,7 \%$ & $25,0 \%$ & $25,9 \%$ & $26,1 \%$ & $26,9 \%$ \\
\hline \multicolumn{7}{|c|}{ Europe 2020 célok és kapcsolódó indikátorok } \\
\hline & 2008 & 2009 & 2010 & 2011 & 2012 & 2013 \\
\hline Foglalkoztatás & \multicolumn{6}{|c|}{ Cél: a foglalkoztatás szintje érje el a 20-64 év közötti népesség 75\%-át } \\
\hline Fogyatékkal élők & $46,4 \%$ & $46,1 \%$ & $46,0 \%$ & $46,9 \%$ & $47,9 \%$ & $48,5 \%$ \\
\hline Teljes népesség & $68,7 \%$ & $67,6 \%$ & $67,3 \%$ & $67,3 \%$ & $67,0 \%$ & $66,9 \%$ \\
\hline \multicolumn{7}{|c|}{ Munkanélküliségi ráta (20-64) } \\
\hline Fogyatékkal élők & $15,9 \%$ & $17,3 \%$ & $18,0 \%$ & $17,4 \%$ & $18,1 \%$ & $19,0 \%$ \\
\hline Teljes népesség & $8,4 \%$ & $10,2 \%$ & $10,9 \%$ & $11,2 \%$ & $12,2 \%$ & $12,9 \%$ \\
\hline \multicolumn{7}{|l|}{ Aktivitási ráta (20-64) } \\
\hline Fogyatékkal élők & $55,1 \%$ & $55,8 \%$ & $56,1 \%$ & $56,7 \%$ & $58,5 \%$ & $59,8 \%$ \\
\hline Teljes népesség & $75,0 \%$ & $75,2 \%$ & $75,5 \%$ & $75,8 \%$ & $76,3 \%$ & $76,8 \%$ \\
\hline Korai iskolaelhagyás & \multicolumn{6}{|c|}{$\begin{array}{l}\text { Cél: a korai iskolaelhagyók aránya kevesebb, mint } 10 \% \text { (18-24 év közötti népesség arányában, } \\
\text { maximum középfokú végzettséggel, akik nem vesznek részt képzésben). Indikatív adatok. }\end{array}$} \\
\hline Fogyatékkal élők & $25,1 \%$ & $23,0 \%$ & $21,6 \%$ & $18,9 \%$ & $21,8 \%$ & $21,5 \%$ \\
\hline Teljes népesség & $13,2 \%$ & $13,1 \%$ & $12,7 \%$ & $11,6 \%$ & $11,2 \%$ & $10,4 \%$ \\
\hline Felsőfokú végzettség & \multicolumn{6}{|c|}{$\begin{array}{l}\text { Cél: a 30-34 közötti népesség 40\%-a rendelkezzen befejezett felsőfokú tanulmányokkal. Indi } \\
\text { katív adatok. }\end{array}$} \\
\hline Fogyatékkal élők & $20,4 \%$ & $21,6 \%$ & $22,8 \%$ & $27,1 \% \%$ & $27,8 \%$ & $28,0 \%$ \\
\hline Teljes népesség & $31,6 \%$ & $33,9 \%$ & $35,5 \%$ & $36,0 \%$ & $38,1 \%$ & $39,3 \%$ \\
\hline
\end{tabular}

Forrás: Grammenos (2015) 11. o. alapján a szerzők kiemelése

\section{Eszközök és szolgáltatások}

Az uniós tagállamok ösztönző rendszerei a már korábban említett főáramba helyezést preferálják, mindegyik országban megtalálható a bérszubvenció, a képzési támogatás, a védett foglalkoztatás és a támogatott foglalkoztatás. A foglalkoztatási támogatások meghatározó részét - a legtöbb országban a nyílt munkaerőpiacon múködő gazdálkodó szervezetek kapják, jóval kisebb arányban részesednek ebből a védett szervezetek.

Az aktív integráció elvének sikeres alkalmazása a különféle elemek közötti együttmúködésen múlik. A megfelelő jövedelemtámogatást munkaerő-piaci lehetőségekkel és jó minőségű szolgáltatásokhoz való könnyebb hozzáféréssel kell kombinálni. A fenntartható munkaerő-piaci integrációhoz a fogyatékos és megváltozott munkaképességú embereknek először megfelelő forrásokat, személyre szóló foglalkoztatási és szociális szolgáltatásokat kell biztosítani. Ha sikerül elhelyezkedniük, elő kell segíteni a munkahely megőrzését annak érdekében, hogy a munkavállaló ne kényszerüljön állása feladására nem megfelelő munkavállalói készségei miatt vagy azért, mert nem tudja sikerrel venni a személyes és társadalmi akadályokat. 


\section{A szolgáltatások szervezeti hátterének változatossága}

A támogatási eszközök fedezetét szolgáló alapokkal döntően az állami foglalkoztatási szolgálatok rendelkeznek és a vonatkozó törvényi előírásoknak vagy kapacitásuknak és kapcsolatrendszerüknek megfelelően biztosítanak különböző szolgáltatásokat. Vannak olyan uniós országok, ahol a szolgáltatásokat kiszervezték, ezek egy részét privatizálták például Hollandiában, Nagy-Britanniában, Ausztriában és Németországban. Ilyen privatizált intézmény Angliában a New Deal for the Disabled, amely azon megváltozott munkaképességú munkanélkülieket segíti a munkába történő visszatéréshez, akik hátrányos helyzetükből adódó támogatásban részesülnek.

A munkaerő-piaci szolgáltatások megvásárlásához tapasztalattal és hatékony módszertannal rendelkező magánszolgáltatókra, fejlett piacra és piaci szereplőkre van szükség. Németországban számos képző intézmény alakult képzési szolgáltatások nyújtására. Ezek elsősorban az érdekvédő társaságokhoz kapcsolódó nonprofit szervezetek voltak. Ezeken kívül alternatív szociális szolgáltatást nyújtó intézmények is megjelentek.

Az állami finanszírozás döntően kétféle elv alapján történik:

1. a költség (input) alapú finanszírozás a szolgáltatók költségeit téríti meg, általában átalány elszámolás (fejkvóta, normatíva) alapján,

2. míg az eredmény (output) alapú finanszírozást a teljesítmény alapján fizetik. ${ }^{10}$

Ugyanakkor több példa is van arra, hogy az állam hoz létre önálló szervezetet, ilyen Belgium Vallónia régiójában múködő ügynökség (Agence Wallone pour l'intégration des personnes handicapées, AWIPH). Feladatkörébe tartozik a fogyatékosság megelőzése, a fizikai akadályok megszüntetésének támogatása, szolgáltatások biztosítása. ${ }^{11}$

A munkáltatók ugyanakkor abban is érdekeltek, hogy az állami foglalkoztatási szervezetektől vagy az általuk finanszírozott civil (alternatív) közremúködőktől megfelelő szolgáltatást kapjanak. Az Egyesült Királyságban nonprofit szervezetként múködik a Business Disability Forum, amely segíti a fogyatékosügyi szakpolitikát, információkat biztosít a munkáltatók számára a megváltozott munkaképességú személyek foglalkoztatásával kapcsolatos előnyökről és nem utolsó sorban segíti a fogyatékossággal élők vállalkozóvá válását. ${ }^{12}$ Utóbbi azért is fontos, mert a megváltozott munkaképességú emberek vállalkozói hajlandósága elsősorban ismeretek hiányában nem jelentős. A nők, az etnikai kisebbségek, a fiatalabb és idősebb fogyatékkal élők és a gazdaságilag depressziós területeken élők nehezebben viszonyulhatnak a vállalkozások megkezdéséhez és sikeres működéséhez. Ez azt sugallja, hogy a fogyatékossággal kapcsolatos politikai intézkedéseket ki kell egészíteni az egyéb társadalmigazdasági helyzethez kapcsolódó hátrányok kezelése érdekében. ${ }^{13}$

\footnotetext{
${ }^{10}$ Scharle Ágota (2008): Alternatív munkaerő-piaci szolgáltatások. Az ellenőrzés, monitorozás, minőségbiztosítás és hatékonyságmérés rendszerei és eszköztára az Európai Unióban. Budapest Szakpolitikai Elemző Intézet

${ }^{11}$ https://www.eurofound.europa.eu/observatories/eurwork/case-studies/egs/agency-for-the-integration-of-people-withdisabilities-belgium

12 http://www.businessdisabilityforum.org.uk/

${ }^{13}$ Kitching, John: Entrepreneurship and self-employment by people with disabilities. Background Paper for the OECD Project on Inclusive Entrepreneurship. OECD 2014
} 
A tartósan munkanélküli fogyatékossággal élő és megváltozott munkaképességű személyek esetében a munkaerőpiacon kívül töltött hosszú időszak alatt meglazulnak a munka világához fúződő kapcsolatok, megkopik a munkavégző képesség. E csoportok visszasegítése a munkaerőpiacra hosszabb folyamat, amely többirányú támogatást kínáló programokat tesz szükségessé. Európa szinte összes országában e programok kombinált intézkedésként, komplex módon tartalmazzák a foglalkozási rehabilitáció, a szubvencionált foglalkoztatás, a támogatott foglalkoztatás, valamint az intenzív tanácsadás elemeit is. Ezekkel többnyire integrált megközelítést valósítanak meg, és olyan testreszabott megoldásokat alkalmaznak, amelyben szükségletvezérelt támogatásokat biztosítanak foglalkoztatásba kerülésük (vagy bennmaradásuk) érdekében. ${ }^{14}$

A munkáltatók érdekeltségi rendszerének jellemző eszköze a kötelező foglalkoztatási kvóták előírása. A kvótarendszer úgy kívánja bővíteni a fogyatékossággal élő emberek foglalkoztatását, hogy kötelezi a munkaadókat bizonyos számú fogyatékos munkavállaló alkalmazására. Ausztriában például azok a munkáltatók, akik legalább 25 munkavállalót foglalkoztatnak, egy kedvezményezett fogyatékos személyt kötelesek foglalkoztatni. Olaszországban azok a munkáltatók, akik legalább 15 főt - és legfeljebb 35 főt foglalkoztatnak egységesen minimálisan 1 fő fogyatékos munkavállalót is foglalkoztatni kötelesek, azok a munkáltatók pedig, akiknek a munkavállalói létszáma meghaladja a 35 főt, de nem éri el az 51 főt, azok 2 fő fogyatékkal élő munkavállalót kötelesek foglalkoztatni. Ha ezt a kötelezettséget a munkaadó nem teljesíti, kompenzációs adót kell fizetnie, s ez szolgál forrásul bizonyos rehabilitációs tevékenységek finanszírozására. ${ }^{15}$

A változó gazdasági és foglalkoztatási környezet és az a foglalkoztatottság növelése iránti igény miatt számos tagállamban erőfeszítésekre került sor egyéb új foglalkoztatási formák lehetőségeinek feltárása érdekében. Ezek közé tartozik az ún. „harmadik szektor”, a szociális gazdaság foglalkoztatási potenciálja, nevezetesen a szolgáltatási ágazaton belül a társadalmilag hasznos tevékenységek körében történő (főleg helyi) munkaalkalom teremtés, különösen Németországban és Franciaországban.

\section{Prevenció és fiatalok}

Európában az utóbbi időben felerősödtek azok a támogatási tartalmak, amelyek a megelőzést, a prevenciót, illetve az életút kezdetének támogatását szolgálják. A fiatal fogyatékosok esélyegyenlőségének biztosítása érdekében 2010-től Svájcban, Dániában, Svédországban, Ausztriában, az Egyesült Királyságban és Hollandiában jelentős reformokat hajtottak végre, elsősorban a tekintetben, hogy a fiatal fogyatékosok szakmai rehabilitációja (képzés, foglalkozási ismeretek, pályaorientáció) lehetőség szerint már az orvosi rehabilitáció alatt megkezdődjön.

A reform keretében személyi szükségleteknek megfelelő multidiszciplináris (orvoslás, oktatás, szociológia) csomagokat dolgoztak ki és használnak fel. Dániában a fiatal fogyatékosok foglalkoztatásának elősegítése érdekében előtérbe helyzeték a rugalmas foglalkoztatást, míg Ausztriában és az Egyesült Királyságban megerősödött a tanintézetekben az állami foglalkoztatási szolgálatokkal közösen végzett

\footnotetext{
${ }^{14}$ Magyarországon is múködtek/múködnek ilyen programok, így például az uniós forrásból támogatott Társadalmi Megújulás Operatív Program keretében a Megváltozott munkaképességű emberek rehabilitációjának és foglalkoztatásának segítése vagy az EFOP 1.1.1 Megváltozott munkaképességú emberek támogatása program.

${ }^{15}$ Szellő János (szerk.) (2013): A rehabilitációs kvóta és hozzájárulás hatása a munkáltatók befogadói magatartására Magyarországon. Kutatási zárótanulmány. Készült a „Közösen a jövő munkahelyeiért” Alapítvány támogatásával. PTE, Pécs
} 
életvezetési és pályaválasztási tanácsadás. ${ }^{16}$ Hollandiában a foglalkoztatási törvény külön rendelkezik a fogyatékossággal élő fiatalok társadalmi esélyegyenlőségük biztosításáról, támogatásáról, az ellátási rendszerekről, juttatásokról, és a szolgáltatásokról (Wet arbeidsongeschiktheidsvoorziening jonggehandicapten / Wajong).

A Wajong reformja során kialakított foglalkoztatást elősegítő program szerint minden fogyatékossággal élő fiatal megfelelő támogatást kell, hogy kapjon későbbi munkavállalásához. Az alapgondolat az, hogy az iskola nem más, mint munkaerő-piaci transzfer. Értékelésére 18 éves korában kerül sor eldöntve a további támogatásokat (foglalkoztatást elősegítő eszközök) és szolgáltatásokat (coaching stb.). ${ }^{17}$

\section{Egyéni stratégiák és ösztönzők}

Az egyéni szükségleteken alapuló tervezés a modern rehabilitációban az 1990-as évektől kezdve végbement szemléletváltás során elfogadott alapelv. Eszerint a szolgáltatások során nem a hátrányos helyzetű ember képességeit és adottságait kell figyelembe venni, hanem egyéni szükségleteit. A modern európai szociális, egészségügyi vagy területfejlesztési stratégiai tervezésben ez az egyik legmarkánsabban jelen lévő alapelv.

Szemléletében meghatározó az empowerment, amely komplex, sokdimenziós tevékenységet jelölő fogalom. Annak a folyamatnak a megjelölésére szolgál, amelynek során a megváltozott munkaképességú személy hatni képes önmagára, hatalommal, önálló probléma megoldási képességgel rendelkezik, vagyis képessé válik arra, hogy saját életét irányítani tudja, és céljait képes legyen elérni.

A másik lényeges megközelítés a holisztikus szemlélet, amely szerint a megváltozott munkaképességú ember egész személyével (személyiségével) kell foglalkozni, beleértve az egészségi és szellemi állapotát, képességeit, készségeit. Fel kell tárni a problémák okait, és az okokat kell kezelni, megszüntetni. A holisztikus szemlélet fontos eleme a megelőzés. E nézetek mellett az egész életen át tartó tanulásra vonatkozó kezdeményezéseknek szisztematikusan fókuszba kell állítania a fogyatékossággal élő emberek igényeit. A szakpolitikáknak (oktatás, foglalkoztatás) proaktívan folyamatosan figyelniük kell a potenciálisan érintett fogyatékossággal élő emberekre, a lehető legszélesebb körben fel kell hívni a figyelmet a tevékenységükre.

Az átalakuló munkaerőpiacon a fogyatékossággal élő és megváltozott munkaképességű személyek esetében is újból előtérbe került a flexicurity kérdése. ${ }^{18} \mathrm{~A}$ flexicurity e két alapvető igényt próbálja egyesíteni: a rugalmas munkaerőpiac és a megfelelő biztonság kombinációját szorgalmazza. A rugalmasság és biztonság nem csak a munkaerőpiacra, hanem a foglalkoztatási és fogyatékosügyi szakpolitikára, az ellátórendszerekre, a munkaügyi szervezetekre is vonatkozik.

\footnotetext{
16 Prins, Rienk (2016): Young persons with health conditions: measures on prevention of disability benefit dependency and activation. An overview of selected reforms, experiences and lessons from five countries. BBL, Verkauf Bundespublikationen, Bern

17 Vos, Edwin L.: Measures on prevention of disability benefit dependency and activation of young persons Netherlands: Young persons with Health Problems and Employment.www.bsv.admin.ch/praxis/ forschung/publika. Letöltve: 2017. július 15.

${ }^{18}$ A rugalmasság és biztonság kérdésköre mind a foglalkoztatáspolitika (munkaerőpiac), mind a szabályzórendszer, a munkajog területén is meghatározó, annak ellenére, hogy a flexicuritynek nincs általánosan elfogadott definíciója, egy olyan konstelláció, amely megpróbálja együtt kezelni a munkaerő-piaci szereplők számára biztosítható feltételek rugalmasságát és biztonságát.
} 


\section{Támogatott foglalkoztatás}

A személyre vonatkozó támogatások mindenekelőtt a munkahely megtartását, ezt követően a nyílt foglalkoztatás megvalósítását célozzák, csak ezek sikertelensége esetén szolgálják a védett foglalkoztatást. Európában az integrációt elősegítő ösztönző rendszeren belül az egyik leggyakrabban alkalmazott módszer a széleskörű koordinációt igénylő támogatott foglalkoztatás (TF). ${ }^{19}$

A TF közel harminc országban múködik, eltérő tartalommal (definíciók, szabványok, módszertan), gyakorlattal, létszámmal és finanszírozással. A támogatott foglalkoztatás szolgáltatás rendszerét az Amerikai Egyesült Államokban dolgozták ki az 1970-es évek végén. Az első TF módszert alkalmazó kísérleti projektek során tanulásban akadályozott és intellektuális, értelmi fogyatékossággal élő embereknek kínáltak szolgáltatást. A későbbiekben a módszert kiterjesztették sok, más fogyatékossággal és betegséggel élő ember támogatására.

A támogatott foglalkoztatás módszere azért alakult ki, hogy speciális támogatással segítse a fogyatékossággal élő munkavállalókat alapvető emberi jogaik gyakorlásában és abban, hogy megerősödjön önbecsülésük, hasznosság-tudatuk. A módszer fontos a munkáltatónak, mert értékes, megbízható, lojális munkavállalóhoz jut, sőt társadalmi felelősségvállalása révén jó hírnevét is gyarapítja.

A módszer több elemből áll és egyértelműen a fogyatékos személy munkaerő-piaci esélyeit szolgálja, közvetlen elhelyezés biztosításával. Általánosságban alapja a munkavállalói profil (intelligencia, munkaképesség, szociális alapkészségek, egészségi állapot, szociális körülmények, érdeklődés, célok stb.) és a munkáltatói profil (munkakörnyezet, munkakör elemzése, munkahelyi légkör) egyeztetése, az illeszkedés vizsgálata a munkába helyezés érdekében. A TF lényeges része a betanítás, a beilleszkedés elősegítése és az utánkövetés. ${ }^{20}$

Svédországban az ottani támogatott foglalkoztatásban, a SIUS (Särskilt introduktions- och uppföljningsstöd) programokban 2014-ben 9908 fö vett részt, 43\%-uk harminc év alatti volt. ${ }^{21} 2010$ ben Ausztriában 10850 fő, a Cseh Köztársaságban 19 szolgáltató ügyfeleként 900 fő vett rész az ottani TF-ben. Ugyanebben az időszakban, Norvégiában a 2500 fő, Spanyolországban 14159 fogyatékossággal élő és megváltozott munkaképességű kapcsolódott ilyen típusú rendszerhez. Ausztriában, Svédországban és Norvégiában a finanszírozás és a szervezés központi, míg a Cseh Köztársaságban és Spanyolországban a TF jelentős uniós (ESZA) támogatásból múködik. ${ }^{22}$

\footnotetext{
${ }^{19}$ Magyarországi viszonyokra a Salva Vita Alapítvány adaptálta a TF módszert, felismerve a szolgáltatás hiánypótló jellegét és a benne rejlő lehetőségeket. A Salva Vita Alapítvány 2003-ban kapott először felkérést az Országos Foglalkoztatási Közalapítványtól a TF szolgáltatás terjesztésére. A program célja volt, hogy az országban minél több helyszínen, minél több megváltozott munkaképességű, fogyatékos ember számára legyen elérhető a szolgáltatás. a Salva Vita Alapítvány mellett további hét magyar szervezet múködtet TF szolgáltatást Magyarországon.

${ }^{20}$ Csányi Zsuzsanna - Jásper Éva (2009): Támogatott foglalkoztatás jegyzet ELTE BGGYK Budapest

${ }^{21} \mathrm{https}: / / w w w . a r b e t s f o r m e d l i n g e n . s e$

${ }^{22}$ Supported Employment for people with disabilities in the EU and EFTA-EEA good practices and recommendations in support of a flexicurity approach. Luxembourg: Publications Office of the European Union, 2012
} 


\section{Profiling}

Az egyéni stratégiák kialakításának alapját a jól felépített szolgáltatások jelentik. A munkanélküliek, ezen belül a fogyatékossággal élő és megváltozott munkaképességű személyek foglalkoztathatóságának felmérésére Európában általánosan elterjedt gyakorlat a kompetencia és profiling alapú megközelítés. ${ }^{23} \mathrm{~A}$ profiling, mint ügyfél-kategorizálási rendszer, magában foglalja - a munkavállalás szempontjából releváns - individuális és szakmai képességek, kompetenciák felmérését (vizsgálatát), és az eredmények szembesítését az adott térség munkaerő-piacának követelményeivel. A profiling a korai beazonosítás módszere, arra szolgál, hogy statisztikai eszközökkel, majd a tanácsadói beszélgetés során az ügyféllel kapcsolatosan szerzett szubjektív szempontokat értékelve kimutassák, hogy az adott személy nagy valószínúséggel tartós álláskeresővé válik-e vagy sem. Tulajdonképpen egy kockázatelemezés, amelynél a kockázati faktor azt mutatja meg, hogy az álláskeresőknél, illetve azok egy csoportjánál mekkora a kockázata a tartós álláskeresővé válásnak.

Az egyik ilyen profiling eljárás a MELBA (Merkmalprofile zur Eingliederung Leistungsgewandelter und Behinderter in Arbeit), amelyet használnak a Benelux államokban, Ausztriában és Svájcban, Svédországban, Finnországban, Litvániában, Szlovákiában, Szlovéniában és Olaszországban is. A szoftveralapú eljárás lényeges eleme a közvetlen tanácsadói, szakértő részvétel. A MELBA kognitív funkciókat, pszichomotorikus jellemzőket, kommunikációs készségeket, közösségi kompetenciákat, munkavégző készségeket mér. Meghatározza a jellemző profilokat és összeveti a foglalkozásokkal, illetve a lehetőségekkel. Ugyanakkor modellezni tudja egy esetleges ismeretfejlesztés (képzés) hatásait is. ${ }^{24}$

Utóbbi tekintetében például Ausztriában a foglalkozási rehabilitáció intézményrendszerén belül, az állammal kötött szerződés alapján az egészségkárosodással vagy funkciózavarokkal küzdő, illetve pszichiátriai diagnózissal, pszichikai korlátokkal, halmozott fogyatékossággal rendelkezők célcsoportja esetében a Szakképzési és Rehabilitációs Központ (Berufliche Bildungs- und Rehabilitationszentrum, BBRZ) végzi a rehabilitációs munkát. ${ }^{25} \mathrm{~A}$ fejlesztés team munkában történik (orvos, foglalkoztatási szakértő, szociális szakértő, pszichológus, andragógus stb.). A foglalkoztathatóság megállapítása a foglalkozásegészségi diagnózisból, az orvosi konzultációból, a pszichikai és intellektuális teljesítmény diagnosztikából, a szociális kompetenciák megítéléséből, és a munkahelyi szimulációs rendszerek alkalmazásából áll. Az egyéni rehabilitációs terv elkészítése, vagyis a szakmai követelmények egyéni érdeklődéssel és kompetenciákkal történő egyeztetése az egészségi korlátozottság elemzésével történik, figyelemmel az esetleges és megoldandó szociális problémákra, a környezetre. Külön rehabilitációs tréningrendszert alakítottak a pszichésen akadályozott személyek részére és tanulásra való felkészítést az alacsony iskolai végzettséggel rendelkezők számára. ${ }^{26}$

Megjegyzendő, hogy a pszichés zavarok: szorongások, pánik, fóbiák, kényszeres betegségek, hangulati zavarok, nagyfokú érzelmi fel- és lehangoltság, kedélybetegségek, személyiségzavarok (narcisztikus, hisztériás, antiszociális), és a stressz-hatások a 21. században szinte általánossá váltak, ezzel együtt

\footnotetext{
${ }^{23}$ Magyarországon 2005-ben PHARE program keretében ÁFSZ modernizáció során kezdődött meg egy profiling alkalmazású rendszer kialakítása. Szűk körben került bevezetésre- először az országban található munkaügyi kirendeltségek egyharmadán. A rendszer alapját az elhelyezkedési esélymérő szoftver alkotta, amely kirendeltségi adatokra támaszkodva az adott ügyfél elhelyezkedési valószínúségét mutatta meg. 2007-től az informatikai rendszer átalakítása miatt nem múködött. 2011től TÁMOP program keretében indult el az újbóli fejlesztése, amely ismereteink szerint napjainkban is tart.

${ }^{24}$ Egger-Subotitsch, A. - Liebeswar, C. - Wunderl, A. - Sinnl, W. - Draxl, I - Gruber, M. - Wawrinec. A. (2015): System und Methoden der Beruflichen Rehabilitation in Österreich. Kommunikations- und PublikationsgmbH, Wien

${ }^{25}$ BBRZ székhelyek: Bécs, Linz, Vöcklabruck, Kapfenberg, Klagenfurt és Innsbruck.

${ }^{26}$ Szellő János: Foglalkozási rehabilitáció és diagnosztikai eljárások. In.: A rehabilitáció komplex szemlélete. Szekszárdi Szociális Múhely Tanulmányok (2011). Szerkesztő: Nagy Janka Teodóra. PTE IGYFK, Szekszárd
} 
megnőtt a pszichoszociális fogyatékossággal élők száma. ${ }^{27}$ A pszichikai akadályozottságból adódó tünetek és súlyosabb esetben a pszichoszociális fogyatékossággal élő személyek ellentmondásos megítélése és a támogatási rendszerek logikájában meglévő problémák gyakran vezetnek a munkaerőpiacról való kiszoruláshoz annak ellenére, hogy a mentális/pszichiátriai betegségekben szenvedők nagy része meglévő képességeik alapján vagy azok fejlesztésével alkalmasak lehetnek, illetve alkalmassá tehetők a munkavégzésre. ${ }^{28}$

Németországban a foglalkoztathatóság elősegítésének alapja a négyfázisú integrációs modell, amelynek első szakaszában megtörténik a profiling (kompetenciák, egészség, szociális helyzet, önismeret és egyéni tervek, pszichés állapot, aktivitás, stabilitás, kommunikáció, közösségi kapcsolatok, munkaerőpiaci környezet stb.). Második fázis a célállapot, az alternatívák számbavétele, elemzése, célkitǔzés (elsődleges cél az integráció). Harmadik fázisban történik a szükséges eszközök hozzárendelése, a megvalósítás stabilizálása. Negyedik fázis a megállapodás megkötése, a lehetséges integráció biztosítása. ${ }^{29}$

Németországban, hasonlóan Ausztriához, a foglalkozási rehabilitáció intézményrendszerén belül a szakmai (képzési) rehabilitációt nem állami szervezetek végzik. Ilyen szervezet a BFW (Die Deutschen Berufsförderungswerke), amely tevékenységének finanszírozását a német állam, a szövetségi munkaügyi központok és a helyi források biztosítják. Fő tevékenységei:

- $\quad$ a diagnózis felállítása az FNO és a profiling módszereivel;

- $\quad$ a hagyományos szakképzésen túlmutató képesítési rendszer biztosítása;

- $\quad$ rehabilitációs és integrációs menedzsment létrehozása;

- $\quad$ egyéni integrációs folyamatok szervezése;

- $\quad$ a szak-és személyiségfejlesztés egyenrangúságának biztosítása;

- $\quad$ egyéni és egységes kompetenciafejlesztés; a kapcsolható és felhasználható diszciplínák körének bővítése, alkalmazása. ${ }^{30}$

\section{Összegzés}

A megváltozott munkaképességúek és fogyatékkal élők munkavégző képessége, így lehetőségeik is igen eltérőek. Az életkor, lakóhely, egészségi állapot, családi helyzet, iskolai végzettség tekintetében meglévő jelentős különbségek mellett fontos különbség az is, hogy egyes károsodásoknak látható jelei vannak, míg másoknak nincsenek. Általában a megváltozott munkaképességúek és fogyatékkal élők a munkaerő-piacon hátrányban vannak koruk és képzettségük tekintetében, sokszor számukra nem megfelelő munkahelyen dolgoznak. Mindezt súlyosbítja a képzés és szakmai felkészültség hiánya.

Európában az elmúlt 30 évben kialakult és tanulmányunkban bemutatott gyakorlatok, módszerek megpróbálnak a teljes emberre koncentrálni, azonban a társadalmi, gazdasági változások, nem egy esetben válságok háttérbe szorítottak hátránykezelési intézkedéseket. Az utóbbi időben átalakultak a munka-

\footnotetext{
27 Pszichoszociális fogyatékossággal élő személy minden az, aki hosszan tartó mentális károsodással él, amely számos egyéb akadállyal együtt korlátozhatja az adott személy teljes, hatékony és másokkal egyenlő társadalmi szerepvállalását.

${ }^{28}$ Nemeskéri Zsolt, Pankász Balázs (szerk. 2015): Módszertani kézikönyv: Pszichés zavarok felismerése és kezelése a munkahelyen. Pécsi Tudományegyetem Felnőttképzési és Emberi Erőforrás Fejlesztési Kar, Pécs

${ }^{29}$ Das arbeitnehmerorientierte Integrationskonzept der Bundesagentur für Arbeit (SGB II und SGB III). 20.12.2013 - VERSION 8.0 - INTERN Zentrale der BA Nürnberg 8-20. p.

${ }^{30}$ Szellő János: Foglalkozási rehabilitáció és diagnosztikai eljárások. In.: A rehabilitáció komplex szemlélete. Szekszárdi Szociális Múhely Tanulmányok (2011). Szerkesztő: Nagy Janka Teodóra. PTE IGYFK, Szekszárd
} 
erőpiacok, a munkaerő szempontjából megerősödött a keresletorientáció, melynek okai között megtalálható a globalizáció, a mobilitás, a tudás értékelése. Ugyanakkor érezhetővé vált a szegmentáció, a strukturális különbségekből fakadó leszakadás. A modern munkaerőpiacon a fogyatékossággal élő és megváltozott munkaképességű emberek munkaerő-piaci esélyegyenlősége akkor tud javulni, ha következetesen érvényesülnek az egész életen át tartó tanulás elveihez kapcsolódó, meghatározó, nemzeti szakpolitikai támogatások.

\section{Bibliográfia}

1. Compendium of good practice Supported Employment for people with disabilities in the EU and EFTA-EEA. Luxembourg: Publications Office of the European Union, 2011.

2. Csányi Zsuzsanna - Jásper Éva (2009): Támogatott foglalkoztatás jegyzet ELTE BGGYK Budapest

3. Das arbeitnehmerorientierte Integrationskonzept der Bundesagentur für Arbeit (SGB II und SGB III). 20.12.2013 - VERSION 8.0 - INTERN Zentrale der BA Nürnberg 8-20. p.

4. Disability mainstreaming int he European Employment Strategy, European Commission, Employment, Social Affairs and Equal Opportunities Dg, Brussels, 1/07/2005

5. Egger-Subotitsch, A. - Liebeswar, C. - Wunderl, A. - Sinnl, W. - Draxl, I. - Gruber, M. Wawrinec. A. (2015): System und Methoden der Beruflichen Rehabilitation in Österreich. Kommunikations- und PublikationsgmbH, Wien

6. Európai fogyatékosságügyi stratégia 2010-2020: megújított elkötelezettség az akadálymentes Európa megvalósítása iránt. COM(2010) 636 végleges. Brüsszel, 2010.11.15

7. Grammenos, Stefanos (2015): European comparative data on Europe 2020 \& People with disabilities. Draft report. Academic Network of European Disability experts (ANED). Centre for European Social and Economic Policy (CESEP ASBL. Bruxelles

8. Kitching, John: Entrepreneurship and self-employment by people with disabilities. Background Paper for the OECD Project on Inclusive Entrepreneurship Kingston University, OECD 2014. 19-20. $p$

9. Nemeskéri Zsolt - Pankász Balázs (szerk. 2015): Módszertani kézikönyv: Pszichés zavarok felismerése és kezelése a munkahelyen. Pécsi Tudományegyetem Felnőttképzési és Emberi Erőforrás Fejlesztési Kar, Pécs

10. Scharle Ágota (2008): Alternatív munkaerő-piaci szolgáltatások. Az ellenőrzés, monitorozás, minőségbiztosítás és hatékonyságmérés rendszerei és eszköztára az Európai Unióban. Budapest Szakpolitikai Elemző Intézet

11. Supported Employment for people with disabilities in the EU and EFTA-EEA good practices and recommendations in support of a flexicurity approach. Luxembourg: Publications Office of the European Union, 2012

12. Szellő János (2009): A foglalkozási rehabilitáció elmélete és gyakorlata, jegyzet. ELTE BGGYK Budapest

13. Szellő János (szerk. 2013): A rehabilitációs kvóta és hozzájárulás hatása a munkáltatók befogadói magatartására Magyarországon. Zárótanulmány, PTE, Pécs

14. Szellő János: Foglalkozási rehabilitáció és diagnosztikai eljárások. In.: A rehabilitáció komplex szemlélete. Szekszárdi Szociális Múhely Tanulmányok (2011). Szerkesztő: Nagy Janka Teodóra. PTE IGYFK, Szekszárd 
15. Vos, Edwin L.: Measures on prevention of disability benefit dependency and activation of young persons Netherlands: Young persons with Health Problems and Employment. www. bsv. admin.ch /praxis/ forschung/publika. Letöltve: 2017. július 15. 